\title{
Religiusitas Islami dan Kerendahan Hati dengan Pemaafan pada Mahasiswa
}

\author{
Yulia Fitriani, Ivan Muhammad Agung \\ Fakultas Psikologi Universitas Islam Negeri Sultan Syarif Kasim Riau \\ email: yuliaf213@gmail.com
}

\begin{abstract}
Abstrak
Pemaafan merupakan hal yang penting dalam hubungan interpersonal. Banyak faktor yang berperan dalam pemaafan, diantara religusitas dan kerendahan hati.Tujuan penelitian ini untuk mengetahui peran religiusitas Islami dan kerendahan hati terahdap pemaafan pada mahasiswa UIN Suska Riau. Subjek dalam penelitian ini berjumlah 391 mahasiswa UIN Suska Riau. Data dikumpulkan menggunakan alat ukur pemaafan dari Religiusitas Islami dan skala kerendahan hati. Data yang diperoleh dalam penelitian dianalisis menggunakan teknik analisis regresi untuk melihat hubungan antar variabel. Hasil penelitian menunjukkan nilai signifikansi religiusitas Islami dan kerendahan hati) artinya religiusitas Islami dan kerendahan hati memiliki hubungan positif dengan pemaafan. Kontribusi variabel religiusitas Islami dan kerendahan hati terhadap pemaafan sebesar $8,7 \%$. Variabel yang lebih besar pengaruhnya terhadap pemaafan adalah kerendahan hati dibandingkan religiusitas Islami.
\end{abstract}

Kata kunci : Religiusitas Islami, Kerendahan Hati, Pemaafan

\section{Islamic Religiosity and Humility with Forgiveness among Undergraduate Students}

\begin{abstract}
Forgiveness is important in interpersonal relations. Many factors play a role in forgiveness, such as religiosity and humilityThe purpose of this study is to find out the relationship between Islamic religiosity and humility with forgiveness among undergraduate students.. The subjects in this study were 391 students of Suska Riau UIN. Data was collected using forgiveness measures from Islamic Religiosity and the scale of humility. Data obtained in the study were analyzed using regression analysis techniques to see the relationships between variables. The results showed the significance of Islamic religiosity and humility which means that Islamic religiosity and humility have a positive relationship with forgiveness. The variable contribution of Islamic religiosity and humility to forgiveness is $8.7 \%$. Variables that have a greater influence on forgiveness are humility than Islamic religiosity.
\end{abstract}

Keywords : Religiuous Islamic, Humility, Forgiveness

\section{Pendahuluan}

Manusia adalah makluk sosial yang berintraksi dengan individu lain. Berbagai macam sifat, karakter yang dimiliki oleh seseorang dalam menjalin hubungan interpersonal. Nashori (2008) menerangkan bahwa dalam interaksi dengan sesamanya, manusia menghadapi berbagai kemungkinan, termasuk kemungkinan interaksi yang lebih akrab dan sebaliknya. Hubungan yang kemungkinan menimbulkan konflik. Individu yang tersakiti oleh orang lain akan mengeluarkan emosi marah dalam dirinya dan amarah ini dipendam oleh individu dengan memperlihatkan perilaku agresif yang akan menimbulkan sikap balas dendam terhadap 
orang yang menyakiti.

Konflik inilah yang menyebabkan suatu hubungan antar individu menjadi tidak baik sehingga perlu diselesaikan. Salah satu intervensi yang bisa dilakukan dalam penyelesaiannya adalah dengan memaafkan kesalahan orang yang bersalah. Pemaafan menjadi salah satu solusi dalam menyelesaikan perkara dan upaya rekonsiliasi suatu hubungan agar terjalin kembali seperti semula. Sebagai seorang mu'min Islam menekan pentingnya menumbuhkan sikap memaafkan. Oleh karena pemaafan sangat bernilai positif dalam kehidupan manusia dan berkaitan dengan toleransi. Untuk menyelesaikan konflik harus mengedepankan toleransi dan menghilangkan rasa dendam (Khasan, 2017).

Kata pemaafan berasal dari kata bahasa arab Arab al-'afw. Kata al'afw yang terdiri dari tiga huruf, 'ain, fa', dan satu huruf mu'tall. Nashori (2008) kata al-afw terulang sebanyak 34 kali didalam Al Qur'an. Menurut Shihab (2013), kata al-afw pada mulanya berarti berlebihan. Akhirnya kata al-'afw berkembang maknanya menjadi keterhapusan. Memaafkan, berarti menghapus luka atau bekas-bekas luka yang ada di dalam hati.Islam sangat menganjurkan seseorang untuk memaafkan kesalahan orang lain, seperti di dalam surat Ali Imran yang artinya , "Yaitu) orang-orang yang berinfak, baik di waktu lapang maupun sempit, dan orang-orang yang menahan amarahnya dan memaafkan (kesalahan) orang lain. Dan Allah mencintai orang yang berbuat kebaikan". (QS. Ali Imran:134).

Terkait dengan pemaafan, dalam kajian psikologi pemaafan atau forgiveness diberi pengertian yang lebih luas. Pemaafan adalah proses atau hasil dari proses yang melibatkan perubahan emosi dan sikap ke arah positif terhadap indvidu yang melakukan kesalahan (McCullough, Bono \& Root, 2007). McCullough, Worthington, dan Rachal (1997) mendefinisikan pemaafan sebagai set perubahan motivasi dimana seseorang menjadi (a) semakin menurun motivasi untuk membalas terhadap hubungan pasangan yang menyinggung; (b) semakin menurun motivasi untuk mempertahankan kerenggangan dengan pelaku, dan (c) semakin termotivasi untuk konsiliasi dan goodwill kepada pelaku, meskipun tindakan menyakitkan dari pelaku. Adapun Thompson, dkk (2005) mendefinisikan pemaafan sebagai upaya seseorang untuk membebaskan respon negatif menjadi netral atau positif terhadap pelaku

Worthington dan Wade menjelaskan bahwa memaafkan memberikan keuntungan bagi kesehatan psikis dan fisik individu serta terapi yang efektif dalam intervensi yang membebaskan seseorang dari kemarahannya dan rasa bersalah (dalam Hasan, 2010). Gassin dan William (dalam Prasetyaningrum \& Silfiasari, 2017) berpendapat bahwa memaafkan dapat mengurangi depresi, kecemasan dan perasaan bermusuh. Kondisi ini didukung oleh hasil penelitian Susanti dan Raudatussalamah (2014) yang menjelaskan bahwa pemaafan memiliki makna penting dalam kehidupan karena memaafkan mempengaruhi kondisi emosional, well being (Sapmaz dkk, 2016),. Pemaafan juga memiliki keuntungan bagi individu dalam membangun hubungan interpersonal (McCullough, dkk 1997; Syamsuddin, 2013). Pemaafan dapat dijadikan sebagai strategi coping dalam menghadapi masalah (Egan, \& Todorov (2009).

Proses pemaafan tidaklah mudah, butuh waktu dan keinginan yang kuat dari indvidu untuk memberi maaf. Beberapa penelitian tentang pemaafan banyak 
ditentukan oleh faktor psikologis, seperti empati (Prasetyaningrum, \& Silfiasari. (2017); Angraini \& Cucuani, 2015; Lestari \& Agung, 2016), well being (McCullough, 2000); kepribadian Big Five (McCullough, dkk, 2001); rumination and emosi McCullough,. dkk (2007),, selain itu, faktor agama juga berperan penting dalam pemaafan (Davis, dkk, 2013), seperti partisipasi agama, hostility, dan kesehatan (Lutjen, dkk 2011), religusitas islami dan kesejahteraan subjektif (Dipengoro \& Ru'iya, 2013). Pada penelitian akan fokus pada aspek religiusitas islami dan kerendahan hati (humility).

Pemaafan punya dua sisi, pertama, sisi dunia, yaitu berkaitan dengan fenomena sosial psikologis dan sisi transendent atau spiritual yang berakar pada agama (McCullough, \& Worthington, 1999). Religuisitas merupakan aspek yang penting dalam pemaafan (Davis, dkk (2013). Menurut Jalaluddin (2016) religio adalah sikap kekhidmatan dalam pemujaan. Religiusitas dimaknakan sebagai pengabdian terhadap agama,. Beberapa penelititan menggambarkan adanya hubungan antara.religusitas dengan pemaafan (Edwards, dkk, 2002; Aiten, 2012) Dengan demikian, religiusitas dapat meningkatkan kecenderungan individu untuk memaafkan. Edwards, dkk (2002) menyebutkan bahwa pemaafan akan mudah diberikan apabila seseorang memiliki tingkat religiusitas yang tinggi.

Krauss (2005) menyebutkan religiusitas secara khusus yaitu religiusitas Islami. Religiusitas Islami merupakan tingkat kesadaran akan Tuhan yang dimengerti menurut pandangan tauhidiah Islam, berperilaku sesuai dengan kesadaran tersebut, atau tingkat manifestasi terhadap kesadaran akan Tuhan dalam kehidupan sehari-hari yang dipahami melalui ajaran
Islam sunni.Menurut Krauss (2005) religiusitas islami terdiri dua dimensi yaitu, pertama, pandangan terhadap agama Islam (Islamic Worldview), yaitu. Pandangan terhadap dunia yang mencerminkan paradigma tauhid Islam (ajaran kesatuan ilahi/keEsaan Tuhan). Konsep ini dapat dilihat dari worldly: tingkat kepercayaan atau pemahaman dari kongruensi Islam dengan kehidupan di dunia dan spiritual : kepercayaan atau pemahaman mengenai hubungan Tuhan dengan ciptaannya-Nya. Kedua, kepribadian Agamis (religious personality), Kepribadian agamis meliputi perilaku, motivasi, sikap dan emosi yang mencerminkan ajaran dan perintah Islam. Dimensi ini terbagi kedalam dua subdimensi, yaitu :ritual, yaitu ibadah yang mencerminkan hubungan langsung seseorang dengan Allah dan Mu'amalat: yaitu hubungan dengan sesama manusia dan hubungan dengan pencipta.

Faktor kedua yang dapat mempengaruhi pemaafan adalah kerendahan hati (tawadhu). Secara etimologi kerendahan hati atau (tawadhu') berasal dari lafaz "عضاوت" artinya merendahkan diri, rendah hati (Yunus, 1973). Menurut Khalid (2013) mengatakan bahwa kerendahan hati atau tawadhu' mempunyai dua makna, pertama menerima kebenaran yang datangnya dari siapa saja, baik orang itu miskin ataupun kaya, terhormat ataupun sederhana, kuat maupun lemah, dari temannya sendiri atau bahkan dari musuhnya. Kedua, tawadhu' adalah mampu menjalin interaksi dengan semua manusia sikap penuh kasih sayang dan kelembutan. Secara global kerendahan hati atau tawadhu' diartikan sebagai "Merendahkan diri dihadapan Allah SWT". Elliot (2010) menyatakan bahwa humility (kerendahan hati) adalah kemampuan untuk mengakui kesalahan diri, ketidaksempurnaan, kesengajaan/ 
keterbatasan diri dan keterbukaan untuk menerima ide-ide baru

Orang yang memiliki sifat rendah hati adalah orang yang terbuka terhadap segala hal yang bersifat positif, merasa memiliki kekurangan dan mau intropeksi diri sehingga ketika ada orang lain yang melakukan kesalahan terhadapnya ia akan berusaha untuk berfikir apakah kesalahan orang itu juga disebabkan oleh perbuatannya. Menurut Asy-Syaqawi (2013) yang dimaksud dengan tawadhu' ialah merendahkan diri dan berlaku lemah lembut. Tawadhu' tidak akan mendongkrak pelakunya menjadi terpuji melainkan hanya untuk mengharapkan ridho Allah SWT..

Elliot (2010) menyatakan kerendahan hati (humility) adalah kemampuan untuk mengakui kesalahan diri, ketidaksempurnaan, kesenjangan/keterbatasan diri dan keterbukaan untuk menerima ide-ide baru, informasi, dan saran. Kerendahan hati juga di anggap sebagai penilaian akurat individu terhadap kemampuan seseorang dan prestasi dirinya. Kaitan antara kepentingan kerendahan hati terhadap pemaafan ditunjukkan dari hasil penelitian Cardak (2013) yang menyatakan bahwa kerendahan hati dapat memprediksi pemaafan. Berdasarkan latar belakang masalah tersebut, maka penelitian ini bertujuan untuk melihat bagaimana peran religiusitas Islami dan kerendahan hati terhadap pemaafan pada mahasiswa.

\section{Metode}

Subjek

Subjek penelitian berjumlah 391 mahasiswa UIN Suska Riau (pria $=148$ dan wanita $=$ 243), dengan rerata umur 20, 4 tahun yang terdiri dari Fakultas Psikologi 18 mahasiswa, Fakultas Pertanian dan Peternakan 25 mahasiswa, Fakultas Dakwah dan IImu
Komunikasi 52 mahasiswa, Fakultas Ekonomi dan IImu Hukum 67 mahasiswa, Fakultas Syariah dan IImu Hukum 59 mahasiswa, Fakultas Ushuluddin 12 mahasiswa, Fakultas Tarbiyah dan Keguruan 90 mahasiswa, dan Fakultas Sains dan teknologi 68 mahasiswa.

\section{Pengukuran}

Metode pengumpulan data pada penelitian ini menggunakan skala. Ada tiga skala yang digunakan dalam penelitian, yaitu Skalapemaafanmodifikasidariskalapemaafan Nashori (2012). Yang terdiri dari tigak aspek yaitu emosi,kognisi dan interpersonal. Skala ini terdiri dari 28 aitem dengan reliabilitas 0.88 . Skala ini menyediakan lima kategori jawaban yang di rangking dari 1 sampai 5 , yaitu 1 (Sangat Tidak Sesuai), 2 (Tidak Sesuai), 3 (Netral), 4 (Sesuai) dan 5 (Sangat Sesuai). Skala religiusitas Islami modifikasi dari skala MRPI (Muslim Religiosity Personality Inventory) oleh Krauss, dkk (2006), yang terdiri dari dua dimensi, yaitu Pandangan terhadap Islam (Islamic Worldview) sebanyak 23 aitem dengan reliabilitas 0.85 dan kepribadian Agamis terdiri dari 33 aitem. dengan reliabilitas 0.95

Skala kerendahan hati modifikasi dari skala Elliot (2010). Skala Kerendahan hati dimodifikasi dari skala humility dari Elliot (2010). Modifikasi dilakukan dengan mengurangi aitem dan menyesuaikan bahasa sesuai dengan kebutuhan peneliti dengan reliabilitas 0.842 Model skala kerendahan hati ini menggunakan model skala Likert. Pernyataan dalam skala yang mengandung kecenderungan favorable yaitu pernyataan yang mendukung pada subyek, diberi nilai sebagai berikut : (Sangat Tidak Setuju) : 1, (Tidak Setuju) : 2, (Tidak Pasti /Netral) : 3, (Setuju) : 4, dan (Sangat Setuju) : 5. Jumlah aitemnya sebanyak 25 aitem dengan 
reliabilitas dengan alpha cronbach sebesar 854.

\section{Analisis Data}

Teknik analisis data menggunakan Regresi dengan bantuan komputerisasi program Statistical of Package for Social Science (SPSS) 24.0 for window.

\section{Hasil}

Hasil uji hipotesis dengan uji regresi ganda sederhana diperoleh (Adjusted Rsq = 0,$087 ; p=0,000$ ) hipotesis dalam penelitian ini diterima. Artinya secara bersamaan ada hubungan yang signifikan antara religiusitas Islami dan kerendahan hati dengan pemaafan pada mahasiswa UIN Suska Riau. Semakin tinggi tingkat religiusitas Islami dan kerendahan hati seseorang maka semakin tinggi pula kesediaannya untuk memaafkan.

Hasil penelitian menunjukkan bahwa Adjusted $R$ square sebesar 0,087 atau $8,7 \%$. Artinya proporsi varian pemaafan yang dijelaskan oleh religiusitas Islami dan kerendahan hati adalah sebesar $8,7 \%$, sedangkan sisanya dipengaruhi oleh ariable lain diluar penelitian ini. Dengan demikian, kemampuan penelitian ini lebih besar dipengaruhi oleh ariable lain dibandingkan dengan variabel religiusitas Islami dan kerendahan hati. Variabel religiusitas Islami dan kerendahan hati yang mempengaruhi pemaafan memiliki hubungan positif. Secara bersamaan besaran Nilai B religiusitas Islami sebesar 0,081 dan kerendahan hati sebesar 0. 221 menunjukkan bahwa yang lebih besar mempengaruhi pemaafan adalah variabel kerendahan hati.

\section{Pembahasan}

Penelitian ini bertujuan untuk melihat hubungan variabel religiusitas Islami dan kerendahan hati dengan pemaafan pada mahasiswa. Hasil penelitian menunjukkan bahwa hipotesis diterima,. Artinya religiusitas islami dan kerendahan hati berperan dalam menentukan pemaafan pada mahasiswa. Indvidu yang yang memiliki religiusitas Islami dan kerendahan hati akan meningkatkan pemaafan pada individu.

Religiusitas berperan penting dalam proses pemaafan. Rhoades dkk (2007) yang menunjukkan bahwa religiusitas dapat mencegah seseorang untuk tidak memaafkan, bahkanmenghindaridariperlakuankekerasan. Hasil penelitian ini didukung oleh hasil penelitian Edwards, dkk (2002) menunjukkan bahwa adanya hubungan yang positif antara religiusitas dan pemaafan Religiusitas Islami mendorong individu untuk menghargai dan memaafkan tanpa yang memungkinkan bagi mereka untuk tidak memaafkan. ketika seorang indvidu memiliki tingkat religiusitas Islami yang tinggi dan mengamalkan nilai-nilai ajaran Islam sebagai dasar untuk memandu kehidupan maka ia akan berpeluang dalam memberikan maaf sebagaimana harusnya. An Nawawi (2014) menjelaskan ciri-ciri mu'min yang baik dalam hubungan sosial menurut polaAI Qur'an adalah mereka yang dermawan, amar ma'ruf nahi munkar, cinta kebaikan dan memaafkan. Sejarah telah mengilustrasikan dengan jelas bahwa pemaafan menjadi nilai dan prinsip dasar yang selalu dijunjung tinggi dalam Islam (Khasan, 2017).

Selain variabel religiusitas Islami, pada penelitian ini juga akan membahas keterkaitan antara kerendahan hati (humility) terhadap pemaafan. Berdasarkan hasil analisis data kategori subjek, penelitian ini menunjukkan bahwa kerendahan hati berperan signifikan untuk meningkatkan pemaafan pada mahasiswa. Penelitian didukung dengan penelitian yang dilakukan oleh Nashori dan 
Kusprayogi (2016) dan Cardak (2013) yaitu terdapathubunganantaravariabelkerendahan hati dengan pemaafan pada mahasiswa. Dalam sudut pandang Islam kerendahan hati (tawadhu) merupakan akhlak serta sifat terpuji, rendah diri yang didorong rasa ikhlas karena Allah SWT dalam rangka mendekatkan diri kepada-Nya dan ingin meraih ganjaran serta kemurahan-Nya kepada makhluk sehingga menjadi ihsan terbaik karena Allah ta'alla (AsySyaqawi, 2013). Sikap menerima kebenaran yang datang dari siapapun, bersikap lembut dan penuh kasih sayang sesama manusia dan kerendahan hati merupakan lawan dari sombong (Khalid, 2013). Orang yang yang kerendah hati mereka yang bersikap lemah lembut terhadap siapa saja sekalipun kepada orang yang pernah menyakitinya dan mengucapkan kata-kata yang baik (Mujib, 2007).

Power dkk (dalam Cardak, 2013) menyebutkan sebagian besar dimensi kerendahan hati terjadi secara konsisten dengan kecenderungan untuk memaafkan. Kerendahan hati bisa menjadi promotor penting untuk pemaafan. Orang yang rendah hati adalah mereka yang tidak menyombongkan diri atas kelebihannya terhadap orang lain. Merujuk pada penelitian sebelumnya oleh Nashori dan Kusprayogi (2016) mereka melihat bahwa dari empat aspek kerendahan hati aspek Oppenes memberikan kontribusi terbesar terhadap pemaafan. Opnnes merupakan membuka diri pada segala hal yang bersifat positif tanpa mempertimbangakan siapa dan dari mana diperoleh. Openness membuktikan bahwa keterbukaan seseorang terhadap suatu hal yang positif serta menganggap tidak ada kelebihan pada diri individu dan juga tidak menganggap orang lain lebih buruk menjadi indikator pertama seseorang memiliki sikap pemaaf. Hal ini menerangkan bahwa keterbukaan individu terhadap orang lain, terbuka secara sosial, empati dan bersahabat adalah salah satu tipe kepribadian individu yang mudah untuk memaafkan.

Penelitian masih menyadari terdapat banyak kekurangan dan keterbatasan. Pertama, terkaiat jumlah dan variasi subjek penelitian yang cenderung homogen, belum melibatkan karakteristik yyang lain seperti orang yang bekerja. Selain itu, perlunya untuk menambahkan variable psikologis lainnya dalam mengeksplorasi pemaafan sehingga dapat menjelaskan pemaafan secara utuh dan komprehensif.

\section{Kesimpulan}

Religisusitas islami dan kerendahan hati merupakan sesuatu yang penting dalam menentukan pemaafan pada indvidu. Hasil penelitian ini menunjukkan religiusitas Islami dan kerendahan hati berperan segnifikan terhadap pemaafan pada mahasiswa. Namun demikian sumbangsih kedua varaibel terhadap pemaafan tidak terlalu besar, oleh karena itu perlunya melakukan penelitian dengan melibatkan variable lain, seperti kepribadian atau tingkat kesalahan serta menggunakan metode lain seperti eksperimen.

\section{Daftar Pustaka}

Ayten, A (2012) How Religion Promotes Forgiveness: The Case of Turkish Muslims, Archive for the Psychology,(3), 411-425), Doi:10.1163/15736121-12341243.

Angraini, D \& Cucuani, H (2014). Hubungan Kualitas Persahabatan dan empati pada Pemaafan Remaja Akhir. Jurnal Psikologi, 10 (1), 18-24.

An-Nawawi,. (2014). Syarah Shahih Muslim/ Imam Nawawi. Jakarta : Darus Sunnah. Terjemahan. Arifin \& Muhammad.

Asy-Syaqawi, S. A.A. (2013). Sifat Tawadhu' 
Rasulullah Shalallahu'alaihi wasallam. Terjemahan. Hidayatullah, Abu, U. A.

Cardak, M.. (2013). The relationship between forgiveness and humility: A case study for university students. Journals academic 8,(8) 425-430, DOI: 10.5897/ ERR2012.1071

Davis, D. E., Worthington, E. L., Jr., Hook, J. N., \& Hill, P. C. (2013). Research on Religion/Spirituality and Forgiveness: A Meta-Analytic Review. Psychology of Religion and Spirituality.5(4) 233-241 doi: $10.1037 / \mathrm{a} 0033637$.

Diponegoro, A.M \& Ru'iya, S.,. (2013). Peran Religiusitas Islami dan Kesejahteraan Subyektif terhadap Pemaafan Remaja Siswa Madrasah Aliyah Negeri III Yogyakarta. PSIKOPEDAGOGIA Jurnal Bimbingan Konseling, 2Doi http:// dx.doi.org/10.12928/psikopedagogia. v2i1.2461

Egan, L.A \& Todorov, N. (2009). Forgiveness as a coping strategy to allow school students to deal with the effects of being bullied: Theoretical and empiricaldiscussion. Journal of Social and Clinical Psychology, 28,(2), 198222.

Edwards, L, Lapp-Rincker, R.H Magyar-Moe, J.J Rehfeldt, J.D. Ryder, J.A, Brown, J.C \& Lopez, S.J(2002). A Positive Relationship Between Religious Faith and Forgiveness: Faith in the Absence of Data?. Pastoral Psychology, 50,(3). $\quad$ http://dx.doi.org/10.1023/ A:1012940402668

Elliott, J. C. (2010). Humility: Development and analysis of a scale. University of Tennessee, Knoxville.

Farraas, A (2013). Hubungan antara Religiusitas Islam dengn Parenting Self-Efficacy pada lbu dari Toddler. Skripsi. Tidak dipublikasikan Universitas Indonesia.

Khalid, A. (2013). Semua akhlak nabi. Solo: Aqwam.

Khasan, M. (2017). Perspektif Islam Dan Psikologi Tentang Pemaafan. Jurnal atTaqaddum, 9(1), 69-94.

Krauss, dkk (2005). The Muslim ReligiosityPersonality Inventory (MRPI): Towards Understanding Differences in the Islamic Religiosity among the Malaysian Yout.
PertanikaJ. Soc. Sci. \& Hum. Vol. 13, No. 2.

Krauss, dkk . (2006). Exploring Regional Differences In Religiosity Among Muslim Youth In Malaysia. Review Of Religious Research, 47(3) 238-252.

Lestari, D.I \& Agung, M.A (2016). Empati Dan Pemaafan Pada Mahasiswa Fakultas Psikologi Uin Suska Riau. Studia Insania 4(2), 137-146

Lutjen, L.J, Silton, N.r \& Flannelly, K.J (2011). Religion, Forgiveness, Hostility and Health: A Structural Equation Analysis, Journal of Religion and Health, , 51, 2, 468-478),DOI: 10.1007/s10943011-9511-7

Mc Cullough, M.E., Worthington, E.L., Rachal, K.C. (1997). Interpersonal Forgiving in Close Relationships. Journal of Personality and Social Psychology, 73(2).

McCullough, M.E \& Worthington, E.L. (1999), Religion and forgiving Personality. Journal Personality,67,1141-1164

McCullough, M E. (2000). Forgiveness As Human Strength: Theory, Measurement, And Links To Well-Being. Journal of Social and Clinical Psychology. 19 (1), 43-55

McCullough, M.E , Bellah, C. G, Kilpatrick, S.D \&. Johnson. J.L (2001). Vengefulness: Relationships With Forgiveness, Rumination, Well-Being, and the Big Five. Personality And Social Psychology Bulletin, $27(5$,$) 601-610$

McCullough,M.E, Giacomo Bono, G \& Root L.M.(2007).Rumination, Emotion, and Forgiveness: Three Longitudinal Studies. Journal of Personality and Social Psychology 92,(3),490-505.

Mujib, A. (2007). Kepribadian dalam Psikologi Islam. Jakarta: PT Raja Grafindo Persada.

Nashori, F. (2008). Psikologi Sosial Islam. Bandung: PT Refika Aditama.

Nashori, F \& Kusprayogi, Y. (2016). Kerendahhatian dan Pemaafan pada Mahasiswa. Psikohumaniora: Jurnal Penelitian Psikologi 1(1), 12-29.

Prasetyaningrum, S \& Silfiasari. (2017). Empati dan Pemaafan dalam Hubungan Pertemanan Siswa Regular Kepada Siswa Berkebutuhan Khusus (ABK) di Sekolah Inkulsif. Jurnal IImiah Psikologi 
Terapan 05 (01),. 126-143

Rhoades et.al.(2007). Forgiving the Perpetrators of the September iith Attacks: Associations with Coping, Distress, and Religiousnees. Anxiety, Stress, and Coping, 20(2): 109128

Sapmaz, F, Yıldırım, M, Topçuoğlu, PNalbant, D \& Sızır, U. (2016). Gratitude, Forgineness and Humility as Predictors of Subjective Well-bUniversity Students. International Online Journal of Educational Sciences 8 (1). 38 - 47.

Syamsuddin, M, M (2013). Efek Intervensi Pemaafan Konseling pada Anak yang terluka dalam Hubungan Interpersonal. Jurnal Psikologi, 9(2), 113-118

Shihab, Q. (2013). "Membumikan" Al-Qur'an: Fungsi dan Peran Wahyu dalam Kehidupan Masyarakat. Bandung : PT Mizan Pustaka.

Susanti, R., \& Raudatussalamah. (2014). Pemaafan (Forgiveness) dan Psyichological Wellbeing pada Narapidana Wanita. Marwah, 13(2.), 219-234

Thompson, dkk. (2005). Dispositional Forgiveness of Self, Others, and Situations. Journal of Personality. 73(2):313-359

Yunus, M. (1973). Kamus Arab Indonesia. Jakarta :Yayasan Penyelenggara Penerjemah. 